\title{
Influential Factors in Oral English Learning
}

\author{
Yuanyuan Gao \& Dawei Zhang \\ Foreign Languages College, Qingdao University of Science and Technology \\ No. 69 Songling Road, Laoshan District, Qingdao 266061, China \\ E-mail: mapleyuan@126.com
}

\begin{abstract}
This paper focuses on influential factors in oral English learning, which are accent, time, and attitude. It analyzes the impact of these factors and figures out effective ways of eliminating. The paper hopes to help Chinese English learners speak good English by means of eliminating accent by imitating Standard English pronunciation and appropriate breathing, taking good advantage of leisure time and holding right attitudes toward English learning so as to improve their oral English.
\end{abstract}

Keywords: Oral English learning, Accent, Time, Learning attitude

Since 1980s, research emphasis in the field of second language acquisition and second language learning has been shifted from presenting language as a set of forms (grammatical, phonological, lexical) which have to be learned and practiced, to presenting language as a functional system which is used to fulfill a range of communicative purposes. This change of emphasis is largely a result of convincing arguments that the ability to use a language should be described as communicative competence.

Communicative competence refers to the ability not only to apply the grammatical rules of a language in order to form grammatically correct sentences but also to know when, where and to whom to use these sentences appropriately.

In China, most English learners, especially students, learn the language mainly for passing various exams but not for communicative purposes. Consequently, one of the pervasive problems for them is that they are just good at taking English exams but with unsatisfied communicative abilities. They seldom use English as a tool to communicate, to express their ideas or to broaden their horizon. On the bright side, more and more learners realize the importance of speaking good English; however, there is a long way for them to speak the language fluently. They will have to overcome the negative influence of factors from their mother language as well as the Chinese culture, such as accent, learning time, attitude and the like. This paper will focus on the impact of these factors and the ways of eliminating their unfavorable effects.

\section{Accent}

\subsection{The influence of accent}

In practice, English is of several varieties as British, American, Australian, Canadian, South African, etc, among which British English and American English are the two most influential ones. British English is easily understood in all English-Speaking countries as it has been studied, investigated, described and recorded more comprehensively and thoroughly than other types. In China, British English has been adopted as the teaching standard in middle schools and colleges for dozens of years. However, in recent years, some learners try to adopt American accent which, generally speaking, includes Eastern American, Southern American and General American. General American is spoken by the majority of the American people, and is widely used in textbooks, radio and TV programs in the U.S.A. (Meng Xianzhong, 2004).

Each type is quite different from others mainly on accents. Therefore, accent plays a very important role in oral English learning. People all over the world have different mother languages which influence the way they speak the second language. In another word, their accent decides the pronunciation when they speak English.

China also has its own English, which is described as "Chinglish". In detail, each Chinese English learner is influenced by their accent when speaking English, and some mistakes are made without being noticed. For example, people in southern China can't distinguish " $n$ " from "l" so well, so they cannot easily tell apart "meaning" from "mealing"; people in northeast China can't distinguish " $\mathrm{j}$ " from " $z$ ", so they always say "enzoy" but not "enjoy". Clearly, the impact of accents really brings a problem for them. 


\subsection{Methods for eliminating accent}

Generally speaking, two methods are helpful in eliminating accent, namely imitating and breathing.

\subsubsection{Imitating}

In dictionary, to imitate means "to copy the behavior, appearance, speech etc. typical of a person."(Longman Dictionary of Contemporary English, 2002) This paper takes it as imitating native speakers' speeches, involving intonation, pronunciation and detailed features of every word said.

It is widely believed that staying in an English-speaking country will definitely help eliminate learners' accent. But as proved by the interviews with excellent English speakers in China by the writer, this method is not as effective as people believed; on the contrary, imitating shows its outstanding favor in eliminating accents. One of the interviewees is an English professor of a university, who finished her master degree in London, England, and speaks excellent and fluent British English. She believes the reason she can speak good English without accent is not because she has stayed in London for many years, but because she imitated BBC news every morning for two years when she was a college student. According to her, people will not correct her pronunciation when she talks to them in London, because they can understand her even with Chinese accent and it'll waste their time. So, Chinese English learners have to eliminate their accents on their own by imitating native news, or speeches.

Moreover, imitating can also help enlarge learners' vocabulary, broaden their horizon, and most importantly, shape their personality. This effective method can be carried out by the following steps:

First, learners have got to make sure the material they are going to imitate is standard and authentic, otherwise they will be in hot water when imitating the wrong passage, wrong pronunciation, and wrong English expression. So, the first step is to choose the right material. Second, they should get a tape machine ready, such as a MP3, or a MP4, to broadcast the imitating material. Third, they can just listen carefully what the tape broadcasts and then record their pronunciation to compare their pronunciation with the standard one, picking up what is wrong or not perfect, and then correct it. They should try to imitate exactly what the tape broadcasts. Then after a couple of months, the way they speak English will be extremely similar with the Standard English in the records.

One significant point in this method is to keep the balance between quantity and quality. After imitating for a long time, learners will take one certain pronunciation and intonation. But if they try to go on with other passages, their pronunciation and intonation will be changed and it's hard for them to obtain the Standard English pronunciation under various influences. So, they may imitate one material for many times to guarantee the imitating quality. Because the more time they spend on imitating one passage, the more points to improve they can detect in pronunciation. That's why they should pay attention to the quality but not the quantity.

\subsubsection{Breathing}

Most American or British people make voice from their chest but not their vocal cords while speaking English. That's why their voices are powerful, melodious and pleasant. Whereas most Chinese English learners speak English just using their vocal cords, so their voices are loud but not impressive.

To sound more pleasant in English speaking, they should try to adopt the "chest-abdomen breathing" method in breathing. When they inhale, the diaphragm is lowered and the chest cavity extended, but when they exhale, the chest cavity is compressed and the diaphragm is raised again (Meng Xianzhong, 2004). Try to inhale gently and deeply, and exhale slowly and evenly. Li Yang, the founder of Li Yang Crazy English, suggests learners should try to speak English in one breath to enhance the strength when they speak English (2005). According to him, they can take a deep breath, and then speak lots of sentences out in just one breath. Correct breathing can make learners' voice sound more melodious and pleasant to the ear.

\section{Time}

Time plays a very important role in oral English learning. But there is only 24 hours a day for each person. They have to spend a lot of time in sleeping, eating, working, entertaining, and others. Under this condition, English learners complain that they really don't have much time to imitate and to practice their oral English every day. That's a big obstacle blocking in their way toward success in oral English.

In order to overcome the obstacle of limited time, the writer finds a new way to use time effectively. Actually learners don't have to spend many entire hours in oral English learning and practice everyday. There is always some time they don't take good advantage of. They can spare or even squeeze ten or twenty minutes from several parts of their life, such as leisure time.

Leisure time is always available in their daily life. For instance, when getting ready to have breakfast, they can spare five minutes in practicing oral English, another five minutes after breakfast, and then the same with lunch 
and supper. In this way, they will get thirty minutes for each meal. When they go to school, office, and house or somewhere on foot, by bus or by train, they can also practice oral English or imitate some Standard English on their way. When they wait in line to get food, ticket or get on bus, they can also read English sentences at the same time. Everyone can find sufficient splits of leisure time to practice oral English.

\section{Attitude}

Attitude has infinite power to help learners improve their oral English quickly effectively. For example, their positive attitude helps them figure out proper time practicing oral English every day. Otherwise, they will achieve nothing if they believe they can never speak good English.

It is suggested that in English learning, English learners should have a general belief "No pains, no gains". In Fa Mulan, an American movie, there is one sentence telling the truth of everything-- "The world is full of opposites" (Fa Mulan). Pay and gain is one pair of opposite but in good balance. People will gain a little if they pay a little. It is the same in English learning.

Another belief which deserves to be mentioned is "God is fair". Some learners practice their oral English for a month, but there is no obvious change or improvement in their oral English. So they give it up, believing that god is unfair. Actually, it's themselves but not God that is unfair to them. After one-month practice, they've got some change and improvement, which they don't notice. Their giving-up makes all their former efforts in vain. That's why they are really unfair to themselves.

The ability to persist is of the same importance in oral English practice. To persist doesn't mean to be pigheaded, but to do something with the right method with the right attitude at the right time. Li Yang said "Persistence Produces Miracle" (2005). His success in English proves the importance of persistence. He began to practice his oral English when he was a sophomore in Lan Zhou University. After one-year study and practice, he was regarded as an insane boy and didn't find any improvement in his oral English. Many friends of his tried to persuade him to give up, but he didn't. He continued to practice every early morning in the mountain, and two years later, he made it. He can speak amazingly good English, which surprised his friends and teachers.

Oral English learning is really important in modern time. Up to now, lots of learners are still suffering from it. Some of them may not realize the influence of their accent, not know how to find effective study time and why they fail so many times to get satisfactory improvement even with a lot of practice. This paper hopes to help learners work out their problems in oral English study, help them set the appropriate goal, encourage them to continue to practice, and to achieve their goals.

\section{References}

Joshiwa. (2005). Love is Specia 1. Ideas, (9): 1-2.

Malcolm Gladwell. (2001). The Tipping Point. New York Boston.

Michael Yu. (2004). The Relentless Pursuit of Success. Thomson Publishing Company. 